\title{
Yield, Yield Components and Soil Characteristics of Sunflower (Helianthus annuus L.) Cultivars under Effect of Nitrogen Fertilizer and Defoliation
}

\author{
Abdullah Ahmed Bjaili, Samir G. Al-Solaimani and Fathy S. EL-Nakhlawy \\ Department of Arid Land Agriculture, \\ Faculty of Meteorology, \\ Environment \& Arid Land Agriculture, \\ King Abdulaziz University
}

\begin{abstract}
This study was conducted in 2017 and 2018 seasons to investigate the effects of 3 nitrogen fertilizer rates $(100,200$ and $300 \mathrm{~kg} \mathrm{~N} / \mathrm{ha}$ ), 3 defoliation levels ( $0.0,2$ and 4 leaves/plant) on yield attributes and yield of 3 different sunflower cultivars ( Egyptian cv. Sakha -53, Argentina cv. Argentina -11 and Turkish cv. May Hybrid ). The experiments were conducted in the Agriculture Research station of king abdulaziz university at Hada Al-sham. The experiments were laid out in split plot design using 4 replicates. The results showed that there were significant effects of the treatments and their interactions on sunflower yield and yield parameters, and on soil characteristics. Nitrogen fertilizer rate $300 \mathrm{~kg}$ N/ha increased sunflower head diameter, seed weight per plant, seed yield per hectare, and increased soil nitrogen percentage and soil organic matter $(\mathrm{OM} \%)$, while soil $\mathrm{pH}$ was significantly reduced. Defoliation of 4 leaves of the plant bottom at flowering stage significantly affected yield components of sunflower cultivars, head diameter, seed weight per plant, weight of 100 seeds and total seed yield $\mathrm{kg} / \mathrm{ha}$. The highest seed weight/plant, 100 -seed weight and total seed yield/ha were obtained by the sunflower cultivar 'Argentina' under nitrogen rate $300 \mathrm{~kg} / \mathrm{ha}$ and removal of 4 leaves. The highest head diameter was obtained by 'Sakha' under nitrogen rate $300 \mathrm{~kg} / \mathrm{ha}$ and removal of 4 leaves from plant bottom at flowering stage. Highest soil nitrogen continents was obtained by 'Sakha' and applying $300 \mathrm{~kg} / \mathrm{ha}$ and removal of 4 leaves, and highest soil organic matter (OM\%) was obtained by 'May Hybrid' and applying $300 \mathrm{~kg} / \mathrm{ha}$ nitrogen and removal of 2 leaves.
\end{abstract}

Key words: Sunflower, Defolation, Nitrogen, Soil characteristics, Fertilizer.

\section{INTRODUCTION}

Sunflower (Helianthus annuus L.) is an important crop plant, it ranks third to the oil producing plants in the world, and it grows well in arid lands, besides its leaves represents good forage products. There was significant increase in seed production, with increase in the nitrogen fertilization rate from zero to $184 \mathrm{~kg} \mathrm{~N} /$ ha (Salih, 2013). N fertilization significantly increased head diameter in sunflower (Aripa et al. 2016). There was reduction in sunflower seed yield below the expected levels with application of nitrogen fertilizer at a rate of 90 to $195 \mathrm{~kg} / \mathrm{ha}$ in the form of ammonia nitrate (Russo and Fish, (2012). Yield production and nitrogen efficiency of safflower qualities have been improved and increased by the addition of nitrogen fertilizer (Shahrokhnia and Sepacehah 2016). Application of $\mathrm{N}$ at rates of 0, 100, and $200 \mathrm{~kg}$ per hectare on two safflower cultivars, and increased head diameter, and increased seed yield in fertilized plants compared to non-fertilized plants (Dordas, and Sioulas, 2009). Addition of nitrogen fertilizer to the sunflower increased seed production (Zubillaga et al., 2002 and Koutroubas et al., 2008). High yield and yield components of sunflower cultivars were achieved by (Giza 102, Sakha 53) cultivar with increase in $\mathrm{N}$ rates $(15,30,45 \mathrm{~kg}$ nitrogen / fed) In Egypt (Abd EL-Satar, et al., 2016). Sunflower hybrids attained the maximum production of sunflower seeds (4.031 $\mathrm{t} / \mathrm{ha}$ ) at $93 \mathrm{~kg}$ of nitrogen per hectare (Mina Kiani et al., 2016). Three Sunflower cultivars were treated with three defoliation levels (without removing leaves, removing 4 leaves and removing 8 leaves) and the highest values for, head diameter, number of seeds per disc, 1000 seed weight, total seed production were for the treatment without removing of leaves (AL-Dori and Hassan, 2011). Under application of defoliation at four levels $(0-4-8-12$ leaves removal) from the stem base of the sunflower plants before the start of flowering, there were significant increase in head diameter and weight of 1000 seeds (Karadogan et al., 2009). Defoliation up to 3 leaves / plant from the stem base of the plant after the end of flowering did not significantly affected seed yield or seed oil content (El-Nakhlawy, 2002). There was reduction in seed weight in castor oil plants due to removal of leaves from the plant (Severinoa et al., 2010). The results obtained from removal of leaves from garlic plants at four levels of leaf removal: 0, 33, 66 and $100 \%$ at seven different stages of growth in Spain showed significant relationship between low production and defoliation, and the greater the clearance of leaves, the lower the production of seeds. 


\section{MATERIALS AND METHODS:}

\section{Experimental site}

This study was carried out in the Agricultural Research Station at Hada Al Sham, King Abdul Aziz University in 2017 and 2018 cropping seasons, to study the effects of N, defoliation and cultivar treatments on the sunflower crop growth and its components and seed quality. The experiments were laid out in in split- split plot design using four replicates. The nitrogen fertilizers rates (N1: $100 \mathrm{~kg}$ $\mathrm{N} / \mathrm{ha}, \mathrm{N} 2: 200 \mathrm{~kg} \mathrm{~N} / \mathrm{ha}$ and N3: $300 \mathrm{~kg} \mathrm{~N} / \mathrm{ha}$ ) were distributed over the.main plots, The defoliation rates (: F1: without leaf removal F2: Removal of 2 leaves F3: Removal of 4 leaves.) were distributed over the sub-plots and the sunflower cultivars (Cv1: Egyptian cultivar : Sakha - 53, Cv2: Argentina cultivar: Argentina-11, Cv3: Turkish cultivar : May hybrid) were distributed over the sub- sub plots. The plots sizes were $3.20 \mathrm{~m} \times 2.1 \mathrm{~m}$ and contained 8 rows with distance $40 \mathrm{~cm}$ and $30 \mathrm{~cm}$ between plants. Plots were fertilized before planting with mono superphosphate (P2O) at $100 \mathrm{~kg} / \mathrm{ha}$, potassium (K2O) at $100 \mathrm{~kg} / \mathrm{ha}$. The nitrogen rates were applied at equal dosages after 15, 30, 45 and 60 days from planting.

Analysis of soil before planting:

Before planting, the following soil properties were determined:

soil organic matter, soil $(\mathrm{pH})$, soil $(\mathrm{EC})$, and soil $\mathrm{N}$ content according to Pansue and Gautherlou (2006) (Table 1).

TABLE (1) INITIAL SOIL ANALYSIS OF THE EXPERIMENTAL SITE BEFORE PLANTING.

\begin{tabular}{|l|l|l|l|l|l|l|}
\hline \multirow{2}{*}{ Soil Depth } & \multirow{2}{*}{$\mathbf{2}$ pH } & \multicolumn{1}{|c|}{ EC } & \multicolumn{1}{|c|}{ OM } & \multicolumn{2}{|c|}{ (N) } & (mg kg-1) \\
\cline { 3 - 8 } & & dS m-1 & $(\%)$ & \multicolumn{3}{|c|}{} \\
\hline $0-15 \mathrm{~cm}$ & 7.27 & 3.26 & 0.651 & 500 & 42.10 & 570 \\
\hline $15-30 \mathrm{~cm}$ & 7.38 & 2.5 & 0.990 & 700 & 35.30 & 460 \\
\hline
\end{tabular}

\section{Measurements}

Sunflower growth components:

Six random plants were taken within each experimental plot and the following parameters were assessed:

Head diameter $(\mathrm{cm})$, seed weight / head $(\mathrm{g})$, weight of 100 seed $(\mathrm{g})$, seed yield ton/ha.

Data Analysis:

Statistical analysis were done for the results recorded in each season according to the statistical design used. Analysis of variance of the trails means were conducted using SAS program (SAS, 2006). The statistical comparisons of the treatments means will be test by RLSD at $\mathrm{P}<0.05$, according to El- Nakhlawy (2010)

\section{RESULTS}

Effects of nitrogen rates on sunflower yield and yield components

The results obtained by analysis of variability (Table 2) indicate high significant differences $(\mathrm{P} \leq 0.01)$ of head diameter, grain weight / plant, 100 grain weight, yield ton/ha under all nitrogen and defoliation treatments in both seasons. There are significant effects of the interactions between nitrogen fertilizer rates and sunflower cultivars on all measured parameters, while significant interaction between defoliation and the sunflower cultivars with regard weight of 100 grains Table (2).

TABLE (2) ANALYSIS OF VARIANCE OF HEAD DIAMETER, SEED WEIGHT/PLANT,100-SEED WEIGHT AND SEED YIELD/HA OF SUNFLOWER UNDER THE EFFECTS OF NITROGEN FERTILIZER RATES, DEFOLIATION, AND CULTIVARS AND THEIR INTERACTIONS DURING 2016/2017 AND 2017/2018 SEASONS

\begin{tabular}{|c|c|c|c|c|c|c|c|c|c|}
\hline \multirow{2}{*}{ Source of variation } & \multirow{2}{*}{ df } & \multicolumn{2}{|c|}{ Head diameter } & \multicolumn{2}{|c|}{ Seed weight/plant } & \multicolumn{2}{|c|}{ 100-seed weight } & \multicolumn{2}{|c|}{ Seed yield/ha } \\
\hline & & $2016 / 17$ & $2017 / 18$ & $2016 / 17$ & $2017 / 18$ & $2016 / 17$ & $2017 / 18$ & $2016 / 17$ & $2017 / 18$ \\
\hline Replicate & 3 & $1.14 \mathrm{NS}$ & $0.19 \mathrm{NS}$ & $3.92 \mathrm{NS}$ & $11.46 \mathrm{NS}$ & $0.49 \mathrm{NS}$ & $0.12 \mathrm{NS}$ & $0.24 \mathrm{NS}$ & $0.01 \mathrm{NS}$ \\
\hline Nitrogen fertilizer rates $(\mathbf{N})$ & 2 & $27.87 * *$ & $36.69^{* *}$ & $783.91 * *$ & $1583.49 * *$ & $68.37 * *$ & $30.07 * *$ & $13.54 * *$ & $7.82 * *$ \\
\hline Error (a) & 6 & 0.83 & 0.06 & 9.79 & 10.75 & 0.93 & 0.25 & 0.15 & 0.03 \\
\hline Defoliation (D) & 2 & $3.48 * *$ & $0.50 * *$ & $59.01 * *$ & $* * 64.17$ & $1.93 *$ & $1.48 * *$ & $2.06 * *$ & $1.46 * *$ \\
\hline $\mathbf{N} * \mathbf{D}$ & 4 & $0.44 \mathrm{NS}$ & $0.08 \mathrm{NS}$ & $14.35 \mathrm{NS}$ & $12.63 \mathrm{NS}$ & $1.55 \mathrm{NS}$ & $0.34 \mathrm{NS}$ & $0.06 \mathrm{NS}$ & $0.03 \mathrm{NS}$ \\
\hline Error (b) & 18 & 0.58 & 0.06 & 6.88 & 9.94 & 0.70 & 0.20 & 0.16 & 0.03 \\
\hline Cultivars (V) & 2 & $132.78 * *$ & $17.76 * *$ & $1516.57 * *$ & $97.50 * *$ & $535.80 * *$ & $27.87 * *$ & $10.64 * *$ & $7.52 * *$ \\
\hline $\mathbf{N} * \mathbf{V}$ & 4 & $1.32 \mathrm{NS}$ & $2.16 * *$ & $58.05 * *$ & $29.21 *$ & $9.06 * *$ & $0.89 * *$ & $1.27 * *$ & $0.06 *$ \\
\hline$D * V$ & 4 & $0.16 \mathrm{NS}$ & $0.06 \mathrm{NS}$ & $8.93 \mathrm{NS}$ & $12.00 \mathrm{NS}$ & $2.15 *$ & $0.57 *$ & $0.23 \mathrm{NS}$ & $0.03 \mathrm{NS}$ \\
\hline $\mathbf{N} * \mathbf{D} * \mathbf{V}$ & 8 & $0.46 \mathrm{NS}$ & $0.09 \mathrm{NS}$ & $6.29 \mathrm{NS}$ & $14.86 \mathrm{NS}$ & $0.87 \mathrm{NS}$ & $0.33 \mathrm{NS}$ & $0.16 \mathrm{NS}$ & $0.03 \mathrm{NS}$ \\
\hline Error (c) & 54 & 0.55 & 0.05 & 5.71 & 5.31 & 0.64 & 0.20 & 0.14 & 0.02 \\
\hline
\end{tabular}

NS: Not significant at $\mathrm{P} \leq 0.05 *$ : significant at $\mathrm{P} \leq 0.05 * *$ : significant at $\mathrm{P} \leq 0.01$ 


\section{Head diameter and Seed weight / plant (gm):}

There was a significant increase in diameter of the head with increasing rates of nitrogen fertilizer in the two seasons. The longest diameter was under $300 \mathrm{~kg} \mathrm{~N} /$ ha with an average of $14.21 \mathrm{~cm}$ in the first season, $11.87 \mathrm{~cm}$ in the second season (table 3). There was a significant increase in seed weight/plant with increasing rates of nitrogen fertilizer in the two seasons, and the highest seed weight/plant was under $300 \mathrm{~kg} \mathrm{~N} /$ ha with an average of $50.09 \mathrm{gm}$ in the first season, and $47.4 \mathrm{gm}$ in the second season (table 3 ).

\section{Weight of 100 seed and seed yield ton/ha}

There are no significant differences in weight of 100 seeds under all $\mathrm{N}$ fertilizer rates (table 3 ).: The mean values of sunflower seed yield/ha (table 3) show that the highest yield of seed / ha was given under the rate of $300 \mathrm{~kg} \mathrm{~N} /$ ha $(5.21$ tons/ha) in the first season, and 4.38 tons/ha in the second season. There was no significant difference in seed yield under 100 and $200 \mathrm{~kg} \mathrm{~N} /$ ha in the first season while there was significant difference in the second season.

Effects of defoliation rates on sunflower yield and yield components

Head diameter ( $\mathrm{cm}$ ) and Seeds weight/plant ( $\mathrm{gm})$ :

The mean results of head diameter (table 14) under defoliation treatments indicate that the highest values of the diameter of the head resulted with the removal of 4 leaves / plant $(13.65$ and $11.05 \mathrm{~cm})$ and do not significantly differ from removal of two leaves, but exceeded values of the treatment without leaves removal in the two seasons. The mean values of the seed weight/plant (table 4) under defoliation treatments indicate that the highest seeds weight/plant resulted with the removal of 4 leaves / plant (46.34 gm) and do not significantly differ from removal of two leaves during the first season, but exceeded values of both treatments 2 leaves removal and without leaves removal in the two seasons.

Weight of 100 seeds $(\mathrm{gm})$ and Seed yield ton/ha
Also defoliation with removal of 4 leaves significantly dominated the treatment without leaves removal by giving the highest weight of 100 seeds (11.68 and $12.03 \mathrm{gm})$ with no significant difference with treatment 2 leaves removal during both seasons (table 4 ). The highest seed yield $4.67 \mathrm{t} / \mathrm{ha}$ and $4.06 \mathrm{t} / \mathrm{ha}$ was obtained in the treatment with 4 leaves removal with no significant difference with 2 leave removal treatment, but dominating the treatment without leaves removal which in its turn gave 4.23 and $3.66 \mathrm{t} / \mathrm{ha}$ in the first and second seasons respectively (table 4).

Genotypic Effects on sunflower yield and yield components Head diameter $(\mathrm{cm})$ and Seed weight per plant $(\mathrm{gm})$ :

The highest head diameter was significantly obtained by the cultivar Sakha $53(15.11 \mathrm{~cm})$ seconded by Argentina with $13.64 \mathrm{~cm}$ and last of Hybrid May with $11.5 \mathrm{~cm}$ during the first season, while during the second season Argentina cultivar significantly gave the highest head diameter (11.58 $\mathrm{cm}$ ) (table 5). Cultivar Argentina significantly gave the highest seed weight/plant (49.51 gm) and $41.68 \mathrm{gm}$ during first and second seasons respectively, then Sakha 53 with 48.2 and $40.51 \mathrm{gm}$ and the cultivar with the least value of seeds/plant was Hybrid May with 37.67 and $38.58 \mathrm{gm}$ respectively during the two seasons (table 5).

\section{0-Seed weight $(g)$ and seed yield (tonlha):}

Results in table (5) show that Argentina Cultivar significantly dominated both other cultivars giving the highest 100-seed weight $(15.17 \mathrm{gm})$ and $12.84 \mathrm{gm}$ during first and second seasons respectively, and Sakha 53 dominated Hybrid May in the first season with $10.08 \mathrm{gm}$, but during second season no significant difference between these two cultivars. As illustrated in table (5) the cultivar Argentina gave significantly the highest seed yield per hectare $(4.97 \mathrm{t} / \mathrm{ha})$ then Sakha 53 cultivar with 4.64 t/ha, then Hybrid May with the least seed yield (3.91 tha) with significant differences between the 3 cultivars. No significant difference was observed between Argentina and Sakha 53 cultivars during the second season.

TABLE (3) MEANS OF HEAD DIAMETER (CM), SEED WEIGHT/PLANT (G), 100-SEED WEIGHT(G) AND SEED YIELD/HA (T) OF SUNFLOWER UNDER THE EFFECT OF NITROGEN FERTILIZER RATES, DURING 2016/2017, AND 2017/2018 SEASONS

\begin{tabular}{|l|c|c|c|c|c|c|c|c|}
\hline \multirow{2}{*}{$\begin{array}{l}\text { Nitrogen fertilizer rate } \\
(\mathbf{k g N} / \mathbf{h a})\end{array}$} & \multicolumn{2}{l|}{$\begin{array}{l}\text { Head diameter } \\
(\mathbf{c m})\end{array}$} & \multicolumn{2}{l|}{$\begin{array}{l}\text { Seed weight/plant } \\
(\mathbf{g})\end{array}$} & \multicolumn{2}{l|}{$\begin{array}{l}\text { 100-seed weight } \\
(\mathbf{g})\end{array}$} & \multicolumn{2}{l|}{$\begin{array}{l}\text { Seed yield/ha } \\
(\mathbf{t})\end{array}$} \\
\cline { 2 - 10 } & $2016 / 17$ & $2017 / 18$ & $2016 / 17$ & $2017 / 18$ & $2016 / 17$ & $2017 / 18$ & $2016 / 17$ & $2017 / 18$ \\
\hline $\mathbf{1 0 0}$ & $12.45 \mathrm{c}$ & $9.86 \mathrm{c}$ & $40.82 \mathrm{c}$ & $34.25 \mathrm{c}$ & $9.91 \mathrm{c}$ & $10.91 \mathrm{c}$ & $4.26 \mathrm{~b}$ & $3.46 \mathrm{c}$ \\
\hline $\mathbf{2 0 0}$ & $\mathrm{b} 13.38$ & $10.94 \mathrm{~b}$ & $44.47 \mathrm{~b}$ & $39.30 \mathrm{~b}$ & $11.72 \mathrm{~b}$ & $11.85 \mathrm{~b}$ & $4.05 \mathrm{~b}$ & $3.81 \mathrm{c}$ \\
\hline $\mathbf{3 0 0}$ & $14.21 \mathrm{a}$ & $11.87 \mathrm{a}$ & $50.09 \mathrm{a}$ & $47.40 \mathrm{a}$ & $12.62 \mathrm{a}$ & $12.74 \mathrm{a}$ & $5.21 \mathrm{a}$ & $4.38 \mathrm{a}$ \\
\hline RLSD $(\mathbf{0 . 0 5})$ & 0.53 & 0.15 & 1.8 & 1.89 & 0.56 & 0.22 & 0.23 & 0.11 \\
\hline
\end{tabular}

*: Means followed by the same letter are not significantly different according to RLSD at $\mathrm{P} \leq 0.05$.

TABLE (4) MEANS OF HEAD DIAMETER (CM), SEED WEIGHT/PLANT (G), 100-SEED WEIGHT(G) AND SEED YIELD/HA (T) OF SUNFLOWER UNDER THE EFFECT OF DEFOLIATION TREATMENTS, DURING 2016/2017, AND 2017/2018 SEASONS.

\begin{tabular}{|l|c|c|c|c|c|c|c|c|}
\hline \multirow{2}{*}{$\begin{array}{l}\text { Defoliation } \\
\text { treatments }\end{array}$} & \multicolumn{2}{l|}{$\begin{array}{l}\text { Head diameter } \\
\text { (cm) }\end{array}$} & \multicolumn{2}{l|}{$\begin{array}{l}\text { Seed weight/plant } \\
\text { (g) }\end{array}$} & \multicolumn{2}{l|}{$\begin{array}{l}\text { 100-seed weight } \\
(\mathbf{g})\end{array}$} & \multicolumn{2}{l|}{$\begin{array}{l}\text { Seed yield/ha } \\
\text { (t) }\end{array}$} \\
\cline { 2 - 10 } & $2016 / 17$ & $2017 / 18$ & $2016 / 17$ & $2017 / 18$ & $2016 / 17$ & $2017 / 18$ & $2016 / 17$ & $2017 / 18$ \\
\hline Without defoliation & $13.03 \mathrm{~b}$ & $\mathrm{~b} 10.78$ & $43.79 \mathrm{~b}$ & $39.32 \mathrm{~b}$ & $11.23 \mathrm{~b}$ & $11.63 \mathrm{~b}$ & $4.23 \mathrm{~b}$ & $3.66 \mathrm{~b}$ \\
\hline 2 leaves removed & $13.36 \mathrm{bb}$ & $\mathrm{b} 10.87$ & $45.25 \mathrm{a}$ & $39.79 \mathrm{~b}$ & $11.35 \mathrm{ab}$ & $11.83 \mathrm{ab}$ & $4.62 \mathrm{a}$ & $3.94 \mathrm{a}$ \\
\hline 4 leaves removed & $13.65 \mathrm{a}$ & $\mathrm{a} 11.02$ & $46.34 \mathrm{a}$ & $41.83 \mathrm{a}$ & $11.68 \mathrm{a}$ & $12.03 \mathrm{a}$ & $4.67 \mathrm{a}$ & $4.06 \mathrm{a}$ \\
\hline RLSD (0.05) & 0.37 & 0.13 & 1.29 & 1.48 & 0.35 & 0.23 & 0.16 & 0.15 \\
\hline
\end{tabular}

*: Means followed by the same letter are not significantly different according to RLSD at $\mathrm{P} \leq 0.05$. 
TABLE (5) MEANS OF HEAD DIAMETER (CM), SEED WEIGHT/PLANT (G), 100-SEED WEIGHT(G) AND SEED YIELD/HA (T) OF THE STUDIED SUNFLOWER CULTIVARS DURING 2016/2017 AND 2017/2018 SEASONS.

\begin{tabular}{|l|c|c|c|c|c|c|c|c|}
\hline \multirow{2}{*}{ Cultivars } & \multicolumn{2}{|l|}{$\begin{array}{l}\text { Head diameter } \\
(\mathbf{c m})\end{array}$} & \multicolumn{2}{l|}{$\begin{array}{l}\text { Seed weight/plant } \\
\text { (g) }\end{array}$} & \multicolumn{2}{l|}{$\begin{array}{l}\text { 100-seed weight } \\
(\mathbf{g})\end{array}$} & \multicolumn{2}{l|}{$\begin{array}{l}\text { Seed yield/ha } \\
\text { (t) }\end{array}$} \\
\cline { 2 - 10 } & $2016 / 17$ & $2017 / 18$ & $2016 / 17$ & $2017 / 18$ & $2016 / 17$ & $2017 / 18$ & $2016 / 17$ & $2017 / 18$ \\
\hline Sakha 53 & $15.11 \mathrm{a}$ & $10.90 \mathrm{~b}$ & $48.20 \mathrm{~b}$ & $40.51 \mathrm{a}$ & $10.08 \mathrm{~b}$ & $11.45 \mathrm{~b}$ & $4.64 \mathrm{~b}$ & $4.09 \mathrm{a}$ \\
\hline Argentina 11 & $13.64 \mathrm{~b}$ & $11.58 \mathrm{a}$ & $49.51 \mathrm{a}$ & $41.86 \mathrm{a}$ & $15.77 \mathrm{a}$ & $12.84 \mathrm{a}$ & $4.97 \mathrm{a}$ & $4.21 \mathrm{a}$ \\
\hline Hybrid May & $11.30 \mathrm{c}$ & $10.18 \mathrm{c}$ & $37.67 \mathrm{c}$ & $38.58 \mathrm{~b}$ & $8.41 \mathrm{c}$ & $11.21 \mathrm{~b}$ & $3.91 \mathrm{c}$ & $3.36 \mathrm{~b}$ \\
\hline RLSD (0.05) & 0.39 & 0.12 & 1.12 & 1.52 & 0.38 & 0.22 & 0.19 & 0.14 \\
\hline
\end{tabular}

*: Means followed by the same letter are not significantly different according to RLSD at $\mathrm{P} \leq 0.05$.

Interaction effects of nitrogen rates and sunflower cultivars on yield and yield components

There is no significant difference in the interaction of fertilizer rates and cultivars as regard sunflower head diameter, but there are significant differences in the case of seed weight per plant, 100-seed weight and seed yield per hectare (table 6). The significantly higher seed yield and yield components were for Argentina cultivar under 300 $\mathrm{kgN} / \mathrm{ha}$, then the Egyptian cultivar Sakha 53 under 300 $\mathrm{kgN} / \mathrm{ha}$, then the Turkish cultivar Hybrid May under 100 $\mathrm{kgN} / \mathrm{ha}$ during the two seasons. Seed yield ranged between $5.68-3.41 \mathrm{kgN} / \mathrm{ha}$ during the first season and $4.54-2.91$ $\mathrm{kgN} / \mathrm{ha}$ during the second season.

TABLE (6). MEANS OF HEAD DIAMETER (CM), SEED WEIGHT/PLANT (G), 100-SEED WEIGHT (G) AND SEED YIELD/HA (T) OF SUNFLOWER UNDER THE INTERACTION BETWEEN NITROGEN FERTILIZER RATES AND CULTIVARS DURING 2016/2017 AND 2017/2018 SEASONS.

\begin{tabular}{|c|c|c|c|c|c|c|c|c|c|}
\hline \multirow{2}{*}{$\begin{array}{l}\text { Nitrogen fertilizer } \\
\text { rate } \\
(\mathrm{KgN} / \mathrm{ha})\end{array}$} & \multirow[t]{2}{*}{ Cultivar } & \multicolumn{2}{|c|}{$\begin{array}{l}\text { Head diameter } \\
(\mathrm{cm})\end{array}$} & \multicolumn{2}{|c|}{$\begin{array}{l}\text { Seed weight/plant } \\
\text { (g) }\end{array}$} & \multicolumn{2}{|c|}{$\begin{array}{l}\text { 100-seed weight } \\
\text { (g) }\end{array}$} & \multicolumn{2}{|c|}{$\begin{array}{l}\text { Seed yield/ha } \\
\text { (t) }\end{array}$} \\
\hline & & $2016 / 17$ & $2017 / 18$ & $2016 / 17$ & $2017 / 18$ & $2016 / 17$ & $2017 / 18$ & $2016 / 17$ & $2017 / 18$ \\
\hline \multirow{3}{*}{100} & Sakha 53 & 13.91 & 10.27 & 42.43 & 31.86 & 7.84 & 10.04 & 4.02 & 3.82 \\
\hline & Argentina 11 & 13.08 & 10.66 & 45.13 & 36.46 & 14.81 & 11.95 & 5.00 & 3.65 \\
\hline & Hybrid May & 10.36 & 8.64 & 34.92 & 34.43 & 7.10 & 10.74 & 3.77 & 2.91 \\
\hline \multirow{3}{*}{200} & Sakha 53 & 15.10 & 10.72 & 47.61 & 39.58 & 10.35 & 11.15 & 4.51 & 4.13 \\
\hline & Argentina 11 & 13.46 & 11.73 & 47.56 & 39.31 & 15.45 & 13.01 & 4.23 & 4.07 \\
\hline & Hybrid May & 11.60 & 10.37 & 38.24 & 39.02 & 9.36 & 11.37 & 3.41 & 3.24 \\
\hline \multirow{3}{*}{300} & Sakha 53 & 16.32 & 11.72 & 54.58 & 44.58 & 12.06 & 12.43 & 5.39 & 4.67 \\
\hline & Argentina 11 & 14.37 & 12.36 & 55.84 & 50.09 & 17.04 & 13.55 & 5.68 & 4.54 \\
\hline & Hybrid May & 11.95 & 11.53 & 39.85 & 34.43 & 8.76 & 12.24 & 4.54 & 3.94 \\
\hline \multicolumn{2}{|l|}{ RLSD (0.05) } & NS & 0.20 & 1.96 & 1.89 & 0.65 & 0.37 & 0.32 & 0.12 \\
\hline
\end{tabular}

NS: Not significant at $\mathrm{P} \leq 0.05$

Means of soil chemical properties as affected by nitrogen and defoliation rates and sunflower cultivars:

Table (7) illustrates significant differences between $\mathrm{N}$ rates and defoliation treatments and their interactions on soil $\mathrm{pH}$, $\mathrm{EC}, \mathrm{N} \%$ and organic matter percentage (OM\%), and also between cultivars in $\mathrm{N} \%$ and their interactions with $\mathrm{N}$ rates, defoliation treatments and with both $\mathrm{N}$ and defoliation. 
TABLE (7) ANALYSIS OF VARIANCE OF SOIL PH, EC, N, AND OM UNDER THE EFFECTS OF NITROGEN FERTILIZER RATES, DEFOLIATION, CULTIVARS AND THEIR INTERACTIONS AFTER HARVESTING SECOND SEASONS (2017/2018)

\begin{tabular}{|c|c|c|c|c|c|}
\hline Source of variation & df & PH & EC (dSm-1) & $\mathbf{N}(\%)$ & OM (\%) \\
\hline Replicate & 3 & 0.0275 & 0.002 & 0.000005 & 0.00021 \\
\hline Nitrogen rates $(\mathbf{N})$ & 2 & $0.1741 * *$ & 0.017 & $0.000190 * *$ & $0.00617 * *$ \\
\hline Error (a) & 6 & 0.0012 & 0.006 & 0.000000 & 0.00012 \\
\hline Defoliation (D) & 2 & $0.0074 *$ & $0.021 *$ & 0.000005 & $0.00096 * *$ \\
\hline $\mathbf{N} * \mathbf{D}$ & 4 & $0.0637 * *$ & 0.001 & $0.000010 * *$ & $0.00275^{* *}$ \\
\hline Error (b) & 18 & 0.0014 & 0.004 & 0.000002 & 0.00015 \\
\hline Cultivars (V) & 2 & 0.0009 & 0.009 & $0.000052 * *$ & 0.00052 \\
\hline $\mathbf{N} * \mathbf{V}$ & 4 & 0.0071 & 0.006 & $0.000018 * *$ & $0.00099 * *$ \\
\hline $\mathbf{D} * \mathbf{V}$ & 4 & $0.0161 *$ & $0.015^{* *}$ & $0.000022 * *$ & 0.00029 \\
\hline $\mathbf{N} * \mathbf{D} * \mathbf{V}$ & 8 & 0.0102 & $0.013 * *$ & $0.000006^{*}$ & $0.00061 * *$ \\
\hline Error (C) & 54 & 0.005 & 0.003 & 0.000002 & 0.0002 \\
\hline
\end{tabular}

Effects of Nitrogen rates on Soil pH, EC, Nitrogen contents and organic matter

Soil $\mathrm{pH}$ is above 7, and $100 \mathrm{~N}$ rate has the highest $\mathrm{pH}$ (7.76) while $300 \mathrm{~N}$ rate has the lowest $\mathrm{pH}$ (7.62) (table 8). No significant differences were observed in EC of the soil under the different $\mathrm{N}$ rates, and it ranged between $2.21-2.17 \mathrm{dSm}-$ 1 (table 8). Soil $\mathrm{N}$ content increased with increase in $\mathrm{N}$ rate and reached its maximum under $300 \mathrm{kgN} / \mathrm{ha}$ giving $0.049 \%$ (table 8). Soil organic matter increased with increase in $\mathrm{N}$ rates reaching its maximum at $300 \mathrm{kgN} / \mathrm{ha}(0.543 \%)$.

Effects of defoliation rates on Soil pH, EC, Nitrogen contents and organic matter

Soil pH value, EC, Nitrogen contents and organic matter Soil $\mathrm{pH}$ is above 7, and the highest $\mathrm{pH}$ (7.71) was under treatment without leaves removal (table 8). No significant differences were observed in EC of the soil between treatments without leaf removal and 2 leaves removal which dominated 4 leaves removal treatment, and EC ranged between $2.17-2.22 \mathrm{dSm}-1$ (table 8). No significant differences between defoliation treatments in soil $\mathrm{N}$ content which ranged between $0.046-0.047 \%$ (table 8 ). Soil organic matter was the highest under 2 leaves removal treatment $(0.538 \%)$ with no significant differences between the two other treatments (table 8).

Effects of sunflower cultivars on Soil pH, EC, Nitrogen contents and organic matter

Soil pH, EC, Nitrogen contents and organic matter

No significant differences between the different cultivars in soil $\mathrm{pH}$ value and it is above 7 . No significant differences were observed in EC of the soil between cultivars treatments and EC ranged between 2.18-2.20 dSm-1 (table 8). Hybrid May cultivar dominated with $0.048 \% \mathrm{~N}$ content in the soil, and no significant differences between cultivars Sakha 53 and Argentina (table 8). Soil organic matter was the highest under Argentina cultivar $(0.535 \%)$ with no significant differences between the two other cultivars (table 8). 
TABLE (8). MEANS OF SOIL PH, EC, N, AND OM UNDER THE EFFECTS OF NITROGEN FERTILIZER RATES, DEFOLIATION, CULTIVARS AND THEIR INTERACTIONS AFTER HARVESTING SECOND SEASONS (2017/2018).

\begin{tabular}{|c|c|c|c|c|}
\hline Source of variation & & & & \\
\hline Nitrogen rates (kgN/ha) & PH & EC (dSm-1) & $\mathbf{N}(\%)$ & OM (\%) \\
\hline 100 & $7.76 \mathrm{a}$ & $2.20 \mathrm{a}$ & $0.045 \mathrm{c}$ & $0.517 \mathrm{c}$ \\
\hline 200 & $7.70 \mathrm{~b}$ & $2.17 \mathrm{a}$ & $0.046 \mathrm{~b}$ & $0.536 \mathrm{~b}$ \\
\hline 300 & $7.62 \mathrm{c}$ & $2.21 \mathrm{a}$ & $0.049 \mathrm{a}$ & $0.543 \mathrm{a}$ \\
\hline RLSD (0.05) & 0.020 & 0.047 & 0.0005 & 0.006 \\
\hline \multicolumn{5}{|l|}{ Defoliation } \\
\hline Without defoliation & $7.71 \mathrm{a}$ & $2.19 \mathrm{ab}$ & $0.046 \mathrm{a}$ & $0.530 \mathrm{~b}$ \\
\hline 2 leaves removed & $7.69 \mathrm{~b}$ & $2.22 \mathrm{a}$ & $0.047 \mathrm{a}$ & $0.538 \mathrm{a}$ \\
\hline 4 leaves removed & $7.68 \mathrm{~b}$ & $2.17 \mathrm{~b}$ & $0.047 \mathrm{a}$ & $0.528 \mathrm{~b}$ \\
\hline RLSD (0.05) & 0.018 & 0.032 & 0.0007 & 0.006 \\
\hline \multicolumn{5}{|l|}{ Cultivars } \\
\hline Sakha 53 & $7.69 \mathrm{a}$ & $2.18 \mathrm{~b}$ & $0.046 \mathrm{~b}$ & $0.528 \mathrm{~b}$ \\
\hline Argentina 11 & $7.70 \mathrm{a}$ & $2.20 \mathrm{ab}$ & $0.046 \mathrm{~b}$ & $0.535 \mathrm{a}$ \\
\hline Hybrid May & $7.69 \mathrm{a}$ & $2.21 \mathrm{a}$ & $0.048 \mathrm{a}$ & $0.533 \mathrm{ab}$ \\
\hline RLSD (0.05) & 0.035 & 0.026 & 0.0007 & 0.0067 \\
\hline
\end{tabular}

\section{DISCUSSION}

Application of nitrogen fertilization significantly affected yield and yield components of sunflower. Head diameter of sunflower increased with increase in $\mathrm{N}$ rates up to $300 \mathrm{kgN} / \mathrm{ha}$. Seed weight per plant significantly increased with increase in $\mathrm{N}$ rates, and also seed yield per hectare increased with increase in $\mathrm{N}$ rates up to $300 \mathrm{kgN} / \mathrm{ha}$. But $\mathrm{N}$ rates have no effects on weight of 100 seeds. The mostly needed natural element by plants for healthy, hastened and convenient growth is nitrogen fertilizer. And under its addition to the soil $\mathrm{N}$ fulfils all the necessary activities and functions demanded by the plants, and plants respond to $\mathrm{N}$ in a very fast way. High concentration. of nitrogen, leads to an increase in the number of cells and the cell size of the leaf with an overall increase in leaf production, and this may be explained by the fact that nitrogen is a necessary component of amino acids, which are the building blocks of proteins and nucleic acids, which prepare genetic material and protein which are useful in plant growth and also encourage a fast growth as stated by Haque and Jakhro (2001). The results obtained in this study agree with many research results obtained by other workers. Also defoliation treatments significantly affected yield and yield components of sunflower. The highest head diameter, seed weight per plant, weight of 100 seeds and total seed yield per hectare were given by the 4 leaves removal treatment. It might be noted that sunflower plants are able to compensate for the removed leaves either by development of new ones or enlargement of the existing leaves. This is supported by Severinoa et al. (2010) who removed leaves from castor oil plant (Ricinus communis) at rates up to $60 \%$ of the total leaf area to assess the effect of leaf fall on growth and yield components, and found that plants were able to fully regrow the lost leaf area. Also Moriondoa et al. (2003) removed 50\% of the sunflower leaf area in different plant growth stages, and found that removal of leaves during vegetative stage initiated significant increase in the leaf area, which compensated for the decrease in light intercept during the season, while subsequent treatments, during flowering and full flower maturity, showed no increase in single leaf area. The results obtained in this study agree with results obtained elsewhere. Karadogan et al. (2009) tested defoliation effect at four levels ( 0 - $4-8-12$ leaves) from the stem base of the sunflower plants before the start of flowering, and found significant effect of leaves removal on many sunflower traits, including head diameter and weight of 1000 seeds. Severinoa et al. (2010) obtained reduction in seed weight in castor oil plants due to removal of leaves. On the other hand AL-Dori and Hassan (2011) treated 3 Sunflowers cultivars with three levels (without removing leaves, removing 4 leaves and removing 8 leaves) and found that the highest values for, head diameter, number of seeds per disc, 1000 seed weight, total seed production were for the treatment without removing of leaves. Also El-Nakhlawy, (2002) showed that defoliation up to 3 leaves / plant from the stem base of the plant after the end of flowering did not significantly affected 
seed yield or seed oil content. On the other hand, response of sunflower cultivars varied significantly with $\mathrm{N}$ and defoliation treatments. The results obtained in this study revealed significant differences between the sunflower cultivars ( the Egyptian variety Sakha 53, Argentina cultivar and the Turkish variety Hybrid May) in their responses to $\mathrm{N}$ fertilization and defoliation treatments regarding growth and growth components, yield and yield components, sunflower seed qualities and soil characteristics. The results obtained in this research study agree with results obtained by many other researchers. Laura (2015) tested response of two sunflower genotypes to $\mathrm{N}$ fertilization, and found significant differences between cultivars. Presottoa et al. (2017) found significant differences between the varieties of the sunflower in response to the removal of leaves (defoliation). Russo and Fish, (2012) found production of seeds in sunflower differed according to the different cultivars of sunflower. Abd-Elsatar et al. (2016) found that yield, yield components and seed quality were significantly affected by genotypes (Giza 102, Sakha 53 and producing line of L120) yield and yield components as well as their interactions.

\section{CONCLUSION}

The results of this study concluded the significant effects of $\mathrm{N}$, defoliation and cultivars and their interactions on sunflower yield and yield parameters, and on soil characteristics. Application of nitrogen fertilizer up to 300 $\mathrm{kgN} / \mathrm{ha}$ increased sunflower head diameter, seed weight per plant, seed yield per hectare, and increased soil nitrogen percentage and soil organic matter (OM\%). But soil $\mathrm{pH}$ value was reduced by $300 \mathrm{kgN} / \mathrm{ha}$. Removal of leaves (defoliation) significantly affected growth of Sunflower cultivars, and the highest head diameter, seed weight per plant, weight of 100 seeds and total seed yield per hectare were attained under the defoliation treatment of 4 leaves removal. As for sunflower yield and yield components, the best yield and yield components (seed weight/plant, 100-seed weight and total seed yield/ha) were attained by the interaction treatments Argentina cultivar under $300 \mathrm{kgN} / \mathrm{ha}$ with 4 leaves removal (Argentina x $300 \mathrm{~N}$ x 4 leaves). But the best treatment for head diameter was given by the interaction (Sakha 53 x 300 $\mathrm{N} \mathrm{x} 4$ leaves). AS for soil nitrogen percentage (N\%) the best treatment combination was $300 \mathrm{kgN} / \mathrm{ha} \mathrm{x} 4$ leaves removal for Sakha 53 cultivar, and $300 \mathrm{kgN} / \mathrm{ha} \times 2$ leaves removal for Hybrid May, and for the highest soil organic matter (OM\%) the best combined treatments was $300 \mathrm{kgN} / \mathrm{ha} \times 2$ and 4 leaves removal for the three cultivars .

\section{ACKNOWLEDGMENT}

The researcher wish to thanks King Abdulaziz City for Science and Technology for their financial support to this work (1-17 -04-009-0002).

\section{REFERENCES}

[1] M.A. Abd EL-Satar, A.A. Ahmed, T.H.A. Hassan. "Response of seed yield and fatty acid compositionsfor some sunflower genotypes to plant spacing andnitrogen fertilization". Information processing in agriculture 4, 241-252.2017.

[2] S.A.M. Al-Dori. "Effect of Leaves Defoliation and Plant Density on Growth, Yield and Quality of Some Sunflower Genotypes (Helianthus annuus L., Compositae)". College Of Basic Education Researches Journal, 11(3), 724-751. 2011.

[3] C.A. Dordas, C. Sioulas. "Dry matter and nitrogen accumulation, partitioning, and retranslocation insafflower (Carthamus tinctoriusL.) as affected by nitrogen fertilization." Field Crops Research 110: 35-43. 2009.

[4] F.S. El-Nakhlawy. "Effects of plant density, genotype and defoliation timing on sunflower seed yield, yield components and oil contents and fatty acids". .Acta agronomica Hungarica, 34: 123134. 2002.

[5] D. Frazen. "Fertilizing sunflower. NDS U Extension Service, Feb. 2016.

[6] Haque, A.A. Jakhro. "Soil and fertilizer potassium". In A. Rashid, Soil Science (p.261-263). Islamabad: National Book Foundation. 2001.

[7] T. Karadogan, I. Akgun, N. Tindal. "Effect of leaf removal on sunflower yield components and some quality characters". Turkish J. of Field crops, vol.14 NO.2, PP:45-54,2009.

[8] D.K. Koutroubas, D. Papakosta, A. Doitsinis. "Nitrogen utilization efficiency of sunflower hybrids and open pollinated varieties under Mediterranian conditions". Field crop Research vol.107 NO.1, .56-61. 2008.

[9] C. Laura, R. Jach-Smitha, D. Jacksona. "Nitrogen conservation decreases with fertilizer addition in two perennial grass cropping systems for bioenergy." Agriculture, Ecosystems and Environment 204, 62-71. 2015

[10] M. Mina Kiani, M. B, Mostafazadeh-Fard, M. Mahdi Majidi, K. Karchani, H. Gerrit. "Effect of the interaction of water and nitrogen on sunflower under drip irrigation in an arid region". Agricultural Water Management, vol. 171, pp. 162-172. 2016.

[11] M. Pansue, J.Gautheyrou. "Handbook of soil analysis Mineralogical, Organic and Inorganic Methods". Springer. PP. 983. 2006.

[12] V.M. Russo, W.W.Fish. "Biomass, extracted liquid yields, sugar content or seed yields of biofuel feedstocks as affected by fertilizer". Industrial Crops and Products 36, 555-559.2012.

[13] M.N.T. Salih. "Response of sunflower to phosphorus and nitrogen fertilization under rainfed conditions", Sudan HELIA, 36, NO. 58, PP.101-110, 2013.

[14] S. Severinoa, A.O. Maria, M.A. Amanda, S.V. "Leandro.Sequential defoliations influencing the development and yield components of castor plants (Ricinus communisL.)" Industrial Crops and Products 32: 00-404.2010.

[15] M. H. Shahrokhnia, A.R. Sepaskhah. "Effects of irrigation strategies, planting methods and nitrogen fertilization on yield, water and nitrogen efficiencies of safflower". Agricultural Water Management 172, 18-30.2016.

[16] M.M. Zubillaga, J.P. Aristi, R.S. Lavado. "Effect of phosphorus and nitrogen fertilization on sunflower nitrogen uptake and yield". Journal of Agronomy and crop science, vol.118. NO.4, PP.267$276,2002$. 